\title{
STRUGGLES IN BECOMING EMPLOYABLE: NON-TRADITIONAL STUDENT NARRATIVES OF THE TRANSITION FROM HIGHER EDUCATION TO WORKING LIFE IN SWEDEN
}

\author{
AGNIESZKA BRON, \\ CAMILLA THUNBORG
}

\begin{abstract}
The notion of employability has been dominating the higher education policies and strategies of the European Union and other western countries for two decades. From an employability perspective, individuals are responsible for acquiring the skills to find and move between jobs, market themselves, and effectively express their social, personal, and cultural capital. This article focuses on non-traditional students' perspectives of their transition from higher education to working life, especially on the pathways they have taken and the struggles they have experienced in becoming employable. A biographical learning perspective is used to analyse biographical interviews with five female students who were 25 years of age or older, with a non-Swedish background, studying full time. In the students' stories, four transition pathways from higher education to working life were identified: a linear, a parallel, a further education, and a changing career pathway. The five non-traditional students struggled with becoming employable and seemed to be anxious about not being good enough at Swedish; being an outsider as a student; being overqualified; and facing discrimination in the labour market. These employability struggles mainly arise due to the assumption that all graduates are young, Swedish, without children or disabilities, and competing only with their employability within an equal labour market. Thus, the notion of employability still gives little attention to non-traditional students and has negative consequences for them.
\end{abstract}

Keywords

employability struggles, non-traditional students, biographical learning, transition paths 


\section{Introduction}

The article is based on data gained from the EMPLOY European research project concerning the employability of non-traditional students (NTSs), i.e. underrepresented groups in higher education (HE) in terms of age, class, disability, ethnicity, and gender. In particular, the article focuses on NTSs' transitions from $\mathrm{HE}$ to the labour market involving six partners across Europe (United Kingdom, Sweden, Spain, Ireland, Poland, and Portugal). ${ }^{1}$ Employability is defined in its broadest sense as an individual's ability to find, retain, and/or move between jobs (Clarke, 2008). The finding and moving between jobs shifts the focus from being employed towards becoming employable (Williams et al., 2016). From an individual perspective, employability is seen as the individual responsibility for gaining appropriate competencies (Fejes, 2010; Fotiadou, 2020), which can also be related to the ability to market oneself and effectively express one's social, personal, and cultural capital (Nilsson, 2016; Tomlinson, 2017). Clarke (2008), however, suggests that employability discourse pays little attention to 'demographic variables such as age, gender, material status, ethnicity and family responsibilities or physical characteristics' (Clarke, 2008, p. 267). Moureau and Leathwood (2006) argue that employability discourse in the United Kingdom (UK) neglects social inequalities, with negative consequences for nontraditional graduates. Research concerning non-traditional graduates' chances for employment seems to be contradictory. On the one hand, Egerton (2000, p. 63) suggests that 'mature graduates are at a disadvantage to young graduates of both sexes on the labour market', and Sargeant (2001) points out that mature graduates face the same age discrimination as those who never entered or returned to HE. Woodfield (2011), on the other hand, argues that mature graduates do just as well as younger students. In a recent study from the UK, Brooks (2019) critically explores the influence of class, gender, and ethnicity on student engagement with graduate employment opportunities. She suggests that student engagement with the graduate labour market is complex and nuanced, with class, gender, and ethnicity intersecting to influence outcomes; she identifies three groups of behaviour. The first group decided to postpone engagement with the graduate labour market until after they had finished their degree; the second group engaged with employment opportunities but were unable to secure a graduate-level job; and the third 
group also engaged with the graduate labour market and secured employment that required a degree. Brooks concludes that students who move away from home to live at university and who complete work experience as part of their degree are the most successful. It should be noted, however, that wider background factors should be taken into consideration, as graduate employment is not equally accessible to all upon completion of a degree.

In this article, employability is studied from the life perspectives of NTSs and the struggles they experience in becoming employable in their transition from HE to the labour market. The focus is on NTSs, especially mature students (over the age of 25 when they started to study), having a non-Swedish background (not born in Sweden or having both parents not born in Sweden), and studying at university programmes specifically designed to become employable in the human resource management (HRM) sector (later HR).

The article aims to explore NTSs' transitions from HE to working life from their own perspectives. More specifically, we address the following research questions:

1. Which transition pathways could be identified in the stories of NTSs?

2. What kind of employability struggles do these students experience in the transition between $\mathrm{HE}$ and the labour market?

\section{Theoretical underpinnings}

The article takes a biographical learning perspective on transition and employability. A biographical learning perspective views learning as a process in which people continually construct their lives and themselves in relation to their own biography, i.e. their social and ethnic background and previous experiences, as well as to the life settings at present, through storytelling. Alheit and Dausien (2000) uses the concept of biographicity to understand the continual processes in which people are involved when forming their individual lives. However, a biographical learning perspective does not only take the individual aspects of learning into account, as biographical stories are co-constructed in interaction with others. Biographical stories thereby 'constantly seek to remind us of the collective in individual narratives' (Merrill \& West, 2009, p. 184).

Transition is here defined as alternating periods of stability and change that individuals experience over time (Merriam, 2005) in relation to different periods of change or movements between educational settings (Niesel \& Griebel, 2005), geographical places (Hörschelmann, 2011), or different periods of life (Hudson, 1999). In addition to Hörschelmann's (2011) concept, we define transition as a process of biographical learning, where a person's background and previous experiences are constructed between the past and 
the future within the present, and between institutional settings or geographical places. This is narrated in a personal story, constructed in the interaction between, in this case, an interviewer and an interviewee (Thunborg \& Bron, 2019).

In this article, three aspects of biographical learning are crucial for understanding the transitions of NTSs. The first aspect is temporality, which means that students give their individual retrospective narratives of their transition and the struggles they experienced with their employability; second, these narratives are grounded in their biographies, i.e. social and ethnic background and previous experiences; and finally, their narratives are viewed from a collective perspective of what is considered successful in becoming employable, which in turn can lead to personal employability struggles.

\section{The linear and the parallel transition pathways from HE to working life}

From previous literature about student transitions from HE to working life, we selected two ideal types (cf. Ball et al., 2002): a linear and a parallel pathway of transition.

\section{The linear pathway}

The linear pathway could be described as a process in which students first graduate and thereafter start to apply for jobs and make the transition to the labour market. In Sweden, this could be seen as a traditional pathway that focuses on transition as a period after students have formally graduated. Some previous studies focus on professional programmes and on student struggles in becoming a professional, for example an engineer (Axelsson, 2008; Nilsson, 2007), a nurse (Ohlsson, 2009), a teacher (Fransson, 2006), a physician (Axelsson, 2008; Lindberg, 2012; Nilsson, 2007) or a psychologist (Nyström, 2009). These studies more specifically focus on how to relate theory to practice (Axelsson, 2008; Fransson, 2006; Nilsson, 2007; Ohlsson, 2009) or how to handle the shock of reality in practice (Lindberg, 2012). Other studies focus on students studying for a bachelor's degree, for example in political science (Johansson et al., 2008a; Johansson et al., 2008b; Nilsson \& Nyström, 2013), biomedicine (Edström, 2009), or human resource management (Löfgren Martinsson, 2008), and their struggles with the range of jobs for which they can apply (Nyström, 2009; Löfgren Martinsson, 2008) and with how to market themselves to become employable on the labour market (Edström, 2009; Löfgren Martinsson, 2008). 
It is interesting to note that in times in which the notion of employability dominates, the linear pathway is seen as a route of failure rather than of success. Brooks (2019) views this pathway as being like a 'fish out of water' as illustrated by students' lack of career plan: they see themselves as lazy and as struggling with their studies; as students that are focusing on getting better grades; and as students who want to continue to study.

The study by Pitman et al. (2019) on disadvantaged students, based on a survey of Australian graduates from 2014, supports the findings by Brooks (2019), and shows that the linear path does not necessarily lead to employment. '....across all groups, students who had studied full time and/or had studied on campus tended to be less likely to find work post-graduation; these were modes less conducive to undertaking paid work at the same time as studying' (p. 49).

\section{The parallel pathway}

The parallel pathway is when students engage with the labour market during their studies to secure employment. Brooks' (2019) study identifies two different groups related to engagement with the labour market during studies: those who succeed in getting a relevant job and those who do not. The first group is labelled the 'game players'; they are strategically engaged in the labour market and succeed. This can be through an ambitious career plan, finding a place that fits their individual characteristics, returning to/or finding employment related to job satisfaction. The second group is labelled 'between two worlds'. This group includes students searching for a change but facing great barriers in their attempt to find work, or those who, after having parttime jobs, felt that they were not yet ready for work (Brooks, 2019). Pitman et al. (2019) investigated the relationship between disadvantage and graduate outcomes, finding that the parallel path improved graduate opportunities for employment and the likelihood of being employed post-graduation almost tenfold. Seventy percent of graduates reported undertaking paid work in their final year of study; more than 60 percent of those still worked for the same employer after graduation. The disadvantaged students included six categories: low socioeconomic background, Indigenous Australians, residence in regional and remote areas, disabilities, non-English speaking background, and women graduating from male-dominated areas of study.

\section{Methodology}

This study uses a biographical approach for understanding NTSs' transitions and employment struggles from HE to working life, from a biographical learning perspective. There are three reasons for studying NTSs in the HR 
sector. First, research concerning NTSs' chances for employment seems infrequent and often contradictory (Egerton, 2000; Sargeant, 2001; Woodfield, 2011). Second, several studies show that people with different ethnic backgrounds from the majority in the country are generally discriminated against in recruitment processes when they seek employment (see e.g. Baert et al., 2015; Blommaert et al., 2014; Bursell, 2007; Bye et al., 2014). Finally, HR pro-fessionals are often seen as gatekeepers in recruitment (see Osman \& Thunborg, 2019). After graduation, and if considering the HR profession, NTSs will be engaged in recruiting university graduates, and thus be practically involved in implementing the employability policies they learned about.

The Swedish part of the EMPLOY project involved data collection that included 38 biographical interviews with 28 NTSs and graduates (ten students were interviewed twice). All interviewees studied at the HR Programme at Stockholm University. Approximately 75 students start the programme each semester, and they study full time. Questionnaires were sent to all students attending the two last semesters (about 150 students) and with majors in education, psychology, or sociology, in order to explore which of these students were non-traditional, and who would be willing to be contacted for a biographical interview. From this sample, we recruited all 28 NTSs who responded positively; the majority were women. The HR programme is one of the most popular and tends to be dominated by women, born in Sweden, between the ages of 19 and 24. It is a three-year general academic programme leading to a bachelor's degree related to organisation, working life, and the labour market, specifically designed for work within HR. There are about 18 similar programmes at various HE institutions in Sweden. The programme in Stockholm, however, is seen as one of the more theory-based ones. During the first year, participants study behavioural sciences; during the second year, they learn about business, law, and human resource management; in the final year, students choose either education, psychology, or sociology for in-depth studies in which they also write their bachelor theses. After graduation, an optional half-semester internship is provided by the university.

In this article, we analyse the biographical interviews of the students who were 25 years of age or older with a non-Swedish background. In total, we analysed eight biographical interviews with five female students. All were interviewed just before graduation; three of them were interviewed a second time during their transition to working $\operatorname{life}^{2}$; two had children when they started to study (see Table 1).

The two other participants were not available for a second interview. 
Table 1

The non-traditional students' back.grounds (age, gender, ethnicity, and number of children)

\begin{tabular}{|c|c|c|c|c|c|c|c|}
\hline Nicknames & 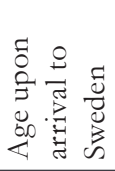 & 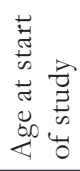 & 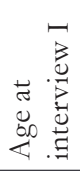 & 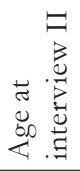 & 苞 & 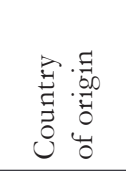 & 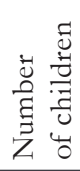 \\
\hline Alexandra & 26 & 30 & 32 & 33 & $\mathrm{~F}$ & Hungary & - \\
\hline Anastasija & 25 & 35 & 38 & 39 & $\mathrm{~F}$ & Poland & - \\
\hline Clare & 40 & 46 & 48 & 49 & $\mathrm{~F}$ & UK & 1 \\
\hline Guadelupe & 15 & 26 & 28 & - & $\mathrm{F}$ & Chile & 1 \\
\hline Liisa & 23 & 26 & 28 & - & $\mathrm{F}$ & Latvia & - \\
\hline
\end{tabular}

A biographical interview usually consists of several narratives in relation to different life periods, life settings, and experiences.

Biographical interviewing is part of biographical research that is concerned with people's stories and experience of everyday life. Using a biographical method means to be engaged in in-depth biographical interviewing. A biographical interview takes place in an interaction between an interviewer and an interviewee, where the interviewee is telling his or her life story without being interrupted. It is a time-consuming process, which requires engagement in narrating, describing and explaining one's own life to the interviewer (Bron \& Thunborg, 2015).

In the first part of the interviews, the students told their life stories without being interrupted. After that, they were asked specific questions about their past, future, and present situation. All interviews contained questions regarding graduates' social and ethnical background and previous experiences before starting to study, as well as their study period and the specific period of transition from HE to working life. When analysing the biographical interviews, we first used open coding to become familiar with the graduates' lives as well as the specific processes of transition through and after HE that were formed as vignettes. From the open coding process, we then identified ideas of transition pathways and different struggles within their employability narratives. In the second step, we analysed each narrative by using selective coding concentrating on (1) the transition paths they were planning to take and/or took to working life; (2) comparing the different transition paths with each other; and (3) identifying the struggles they experienced during the transition. Finally, through the biographical learning perspective lens, we used transition and struggles as sensitising concepts. During the analysing process we found how NTSs' age, social, cultural, and ethnic background, and the notion of employability were reflected in their stories. These factors had an impact on the transitions that graduates expressed and contributed to 
developing the concepts of transition pathway and employability struggles (Thunborg \& Bron, 2018; 2019). As our article consists of eight in-depth interviews with five students, we focused on the variations of their biographies, transition pathways, and employability struggles as NTSs in HE.

In the interviews, we needed to create a relaxed and trusting atmosphere between the researcher and interviewees. Being well experienced in conducting biographical interviews, we are aware that each situation is unique, and rapport is crucial (Bron \& Thunborg, 2015; 2017). Thus, it was important to have in-depth interviews with the researcher listening carefully, giving as much space to the participants as possible, and encouraging them to take the lead to avoid researchers eliciting 'correct' answers. The consent with each participant was written and ethical considerations followed thoroughly.

\section{The stories of five students}

In this section we present stories from the five students: Alexandra, Anastasija, Guadelupe, Claire, and Liisa.

\section{Alexandra's story}

Alexandra was 30 when she began studying at the HR-programme. She had come to Sweden from Hungary nearly a decade before with her husband who had obtained a job at an international company. In Alexandra's family, there was no tradition of studying at the HE level, but her mother had graduated later in life. Alexand ra had studied literature and psychology in Hungary and became a secondary school teacher. When she arrived in Sweden, she could not work in her former profession, so she looked for both a job and opportunities to study. She started learning Swedish, which she considered crucial, and then continued studying to become a healthcare assistant. That gave her an opportunity to work in elder care and improve her Swedish. Nevertheless, she felt she wanted to do something more demanding and important, so she started the HR programme. This suited her perfectly well, as the programme was only three years long and could provide her a gateway to the HR sector. Furthermore, she could study psychology as a specialization, which she had previously studied and really enjoyed. During her studies, other students also told her that psychology was the discipline within the programme that was most in-demand, and as such was more appreciated by prospective employers. Thus, choosing psychology would make it easier to get a job. Her choice, therefore, became a strategy to become employable. As Alexandra had both worked and studied before, she wanted to be able to concentrate on her studies. Therefore, she did not apply for a part-time HR job like other students. She deliberately chose a linear pathway. 
During the programme she learnt about employability skills, which initiated the struggle and doubt about her own chances of getting a job:

During our education, we read many studies and statistics about the most wanted on the labour market... and those who have the best chances to get a job and I am quite down the list, I am a foreigner... that is bad...I am a woman, not so good either, I am over 30 and probably soon having a child, not so good, I have no experience in HR work.

She thought that the competition was enormous, and that her situation as a foreigner made her situation especially hard. She applied for around 40 different jobs with no success. As the recruitment companies, which had employed many of her study mates, did not give her applications any attention, she thought that the recruitment companies were full of young Swedish women, ten years younger than she was, working as gatekeepers for people like themselves. She thought that these first junior jobs were unavailable for people like her and talked about discrimination due to her age, her foreign name, and her inability to speak Swedish perfectly. Finally, she was employed by a company whose personnel had diverse nationalities. Here, her language skills and foreign background were considered an advantage.

In retrospect, Alexandra saw herself as being successful in getting a job, and after a few months, she landed a permanent position in the HR sector:

The day after graduation I started to look for a job and went to the Public Employment Service... I did not search for so many jobs actually ... and from this company they called me back shortly, within a week it was... so it went quite quickly because they needed a recruiter who speaks Swedish, English, and another language as well. That company is active in the construction industry where there are very many who have a foreign background and then it is an advantage that we in the office can speak several different languages. (Alexandra)

From Alexandra's story, we found several life transitions that took place before she started studying at the programme. These transitions included becoming a teacher, moving to Sweden, learning Swedish, becoming an assistant nurse, and finally choosing to study in HE in Sweden. When choosing an educational programme and a subject, she combined her previous interest with a strategy to become employable in the Swedish labour market, and she also chose a linear pathway as she wanted to concentrate fully on her studies. Her transition from HE to the labour market began when she was about to leave the university, but her employability struggles started at the beginning of her studies and increased during her studies when she learnt about the skills that employers were seeking. Thus, rather early in her studies she believed that she had fewer opportunities to find a job because of being older, having another ethnic background, and not speaking perfect Swedish. She 
also drew the conclusion that she was subjected to discrimination after applying for 40 jobs and being unsuccessful, concluding that the junior jobs were not for people like her and that young students acted as gatekeepers in the recruitment process. In retrospect, however, she ended up in a job where her ethnic background was seen as an advantage.

\section{Anastasija's story}

Anastasija comes from a family who moved back and forth between Sweden and Poland throughout her life; therefore she was ambivalent about her national identity early in life. Her parents were educated in Poland: her mother in art education and her father in engineering. She had studied and worked before entering the HR programme at the age of 35 and took pride in being good at Swedish. During her studies, she felt that she had to be active to be accepted among other students, both because she was older and because of her ethnic background:

I felt sometimes that I had to be active to be accepted, take more initiative because no one is going to invite me. I have to show that I am like you or that I am someone to talk to and to have coffee with. (Anastasija)

She also found that some other students with other ethnic backgrounds were subjected to prejudice from other students as they dressed differently:

We have a woman in our class that comes from ... Latvia and I know she is dressed a little different from others, I have noticed that... It is terrible but someone has talked about her, they call her the Russian and I do think it has to do with clothes... We also have a woman from Latin America who has colourful clothes... I notice that they react to that as well, I heard something from someone saying that she just came home from a holiday or was on her way to go to a night club, it is very interesting ... Many of the students are young women, they are very smartly dressed, simple but smart, they wear jackets and jeans, you should be smart but discreet in a Swedish way. (Anastasija)

Anastasija also reflected upon the dress code among younger students as an identification marker within the labour market which contrasted with the dress code of mature students.

We that are a little older think that the younger, who have limited work experiences, try to prove something through their clothes. (Anastasija)

Anastasija identified herself as a mature student, but she also saw herself as a bridge builder between students of different ethnicities, as she spoke nearly perfect Swedish according to others. Anastasija supported herself during her studies with a part-time job by helping people with a criminal background to find their way back into the labour market. Anastasija, like Alexandra, had 
planned to follow the linear pathway; however, one year before graduation, she felt forced to take a part-time HR job to become more employable in the HR sector, and, thus, took a parallel pathway instead. At that time, she realised that employers saw her as already overqualified as she was in her final year; she also found that companies required a three-day-a-week commitment to get employment after HE:

I have applied for some positions as an HR assistant or recruitment assistant ${ }^{3}$ but they've told me quite clearly that you have to have more than a year left of your studies... you should work three days a week.... and then when you have completed your studies you have a chance to start to work full time ... but then they want you to bave worked longer than a year... it feels a little late... and I feel that I am stuck in the middle, not yet finished my studies, and when I finish, I will be overqualified. (Anastasija)

She struggled with getting a part-time HR job; however, during her last semester, she was lucky to land a part-time position at one of the labour unions, which became her gateway to a permanent job in another labour union where her education was useful.

Anastasija started off with a plan to take the linear pathway but changed to a parallel pathway during her last year. Her story also tells us something about how her employability struggles were formed during the programme, where other students positioned themselves in terms of age and ethnicity but also in relation between studies and working life. The struggles led, in Anastasija's case, to changing her pathway from a linear to a parallel one. Finally, she got a relevant job even better than the junior jobs younger students got, despite the fact she was considered to be overqualified.

\section{Guadelupe's story}

Guadelupe came to Sweden as a child, with her mother, sister, and two brothers as refugees from South America. When she was 15, she gave birth to her son and was a single mother from that time. She was 25 years old when she started studying in HE. Previously, she had had various jobs: as a babysitter, a librarian assistant, a salesperson, and an elderly person's caregiver. She also studied business for one year. Guadelupe had moved a lot; at the time of interview, she lived in a small apartment in a disadvantaged suburban area of Stockholm. She experienced life as a university student as tough: not only did she struggle with her studies, but she also struggled with a chronic illness, with being a single mother and working evenings and weekends to be able to support herself as a mother, and with having a disability. Although she got some support from the university and was exempt from some assignments, she had difficulties making friends with her study mates and felt discriminated against, isolated, and lonely: 
... I have to fight, fight. I think if I had not had such problems with my illness, being a single mother, immigrant, living in separation ... I think, I would have gotten much, much better grades... (Guadelupe)

Guadelupe was aware of her own intellectual capacity but not sure if she could get a job in the HR profession, as she thought her Swedish was not good enough and other students were much better than her. She did not, therefore, dare to apply for any jobs:

No, I do not dare! [job hunt] ... because I know they will say no, no. Well, my peers are so good, why should someone want to bire me where there are several [students], you know. So, I dare not seek [a job]. (Guadelupe)

Guadelupe's strategy was to continue to study to get a master's degree in HR. She thought that would give her the social status that she lacked. Her pathway could, therefore, be described as the further education path.

Several struggles in Guadelupe's life affected her choice of a transition pathway. Being a single mother and having to work to support herself, suffering from a chronic illness, not being successful in her studies, not having any student friends and being discriminated against, she developed low selfconfidence and low self-esteem as well as mental illness, and, therefore, she did not dare to even apply for a HR job. Her decision to take the further education transition pathway was, thus, more a way to avoid being rejected in a recruitment process than a choice of interest.

\section{Liisa's story}

Liisa moved to Sweden from Latvia when she was 23. She was the first in her family to study in HE. Before moving to Sweden, she worked as a secretary. She was interested in moving to Sweden and listened to Swedish radio to learn the language. In Sweden she started to work as an au pair in a family and continued learning Swedish. She wanted to learn the language properly to be able to study in HE. However, she returned to Latvia, where she worked and studied to become a pedagogue. As she did not find that interesting, she decided to change her educational programme and began studying English instead. After two years, she returned to Sweden and studied Swedish as a second language at the university. At the age of 26, she began her studies in the HR programme.

As Liisa did not have permanent residency in Sweden, she was not eligible for a study loan, and was forced to secure her living by working during her studies. She worked as an au pair, missed lectures, and failed all her exams during the first semester. She had difficulty becoming part of the study group and gaining friends, as she was often absent. During her second year, she still worked as an au pair but only in the afternoons and evenings, which made 
it easier to concentrate on her study. Her results then became better, but she was still an outsider in the study group. In her last year she applied for a parttime job in recruitment but did not get one. She thought that it might have been too late. She struggled with not having the right experience to get a job:

... and you feel that you have no experience, and it scares you a bit, because it can be really hard to find a job, and when reading [job advertisements], they usually require two or three years of experience as well.... If you don't have it, then it's hard to get it ... (Liisa)

As she was not sure if she would find HR employment, she thought of getting a master's degree. In this way, she was about to choose the further education pathway to be able to compete with others. Liisa's story presents information about the struggles related to studies and the language, having to work to support herself, not being part of a study group, not gaining social networks, and not getting any part-time job in HR. For Liisa, as for Guadelupe, these struggles led her to choose the further education transition pathway.

\section{Clare's story}

Clare was 41 when she moved to Sweden from the UK. Her husband is Swedish. Clare and her brother and sister were the first generation in their family to go to HE. Before moving to Sweden, Clare had a degree in law and psychology, and 20 years of experience as a solicitor. She had started studying Swedish in Scotland, and continued learning the language in Sweden after her arrival. She got a mentor to support her efforts looking for a job as solicitor. As it was not possible to obtain such a job, she had to change her career track:

... I had twenty years of experience as a lawyer and I have always worked and I didn't see that it would be a problem because I also felt that Sweden is a country that very much works in English as there are many international companies, so I thought I must be able to get something without much difficulty, but then quickly you realise that it has not worked at all and I realise that as a lawyer and to use my experience that I would have to, you know, to re-educate myself so that employers might find me attractive...(Clare)

Clare talked to a career adviser at the university and decided to take the HR programme. Being a good student, she wanted to learn as much as possible, both the language and the content. Thus, it was obvious for her she had to study without a part-time job. During her studies, she became aware that she might be too old to be able to get a job; nevertheless, she applied for a parttime HR assistant job and was called in for an interview. She did well during the interview, but she was told that she was overqualified. 
... I just actually thought of getting a part-time job as other students do, have part-time jobs, with sort of the same branch, you know a lot of people are recruiting assistants working in some kind of HR, I think it's great, I have two problems with that: one - my son is only five... After being on the interview ... I got to know that I was overqualified, so I realised I am not fitting the profile to be an HR assistant. (Clare)

She wrote her final essay for the degree and applied for an internship offered in connection with the HR programme.

...yes I have these strategies for what I want and I still do think that I am employable but we will see how it turns out depending on what response I get, but I figure an internship place might do, if I might persuade an employer to take me on the basis of what I would be actually doing or anything ... I will see what's good I will see ... now I am starting the internship course with the HR programme that starts in the spring, so I have my application...(Clare)

However, although Clare successfully graduated, she could not find a company in which she could do her internship. Instead, she started applying for jobs in the HR sector, but was not even called in for interviews. Clare talks about the labour market in Sweden as being narrow-minded and closed for people that are not really seen as the 'ordinary ones', not having the right networks and being old and changing their careers:

... eh, I think marketplaces is extremely closed for people who you know first of all they need networks eh despite that this course highlights you know competencies, it's not competencies you now, there is the ages between 32 and 42, there is your employability that Sweden hires. And, I know that I passed that ... I can work. and have more to give, there is somebody who is 32 and has less experiences than me. Eh I eh, you just know you can be down the pail on the older side, you know, particularly trying to start a new career and again it is contradictory information they can get, as I could see that one wants to encourage people to change careers. (Clare)

She then decided to change her career again and applied for other jobs. Finally, she got a job in the state insurance agency, where she had to work provisionally for six months before gaining permanent employment. Although Clare did find a job, the job is not related to HR. In this way, she once again took the changing career pathway.

It is interesting to understand how Clare changed pathways several times in relation to the struggles she experienced. She started off with the changing career pathway, then wanted to take the linear pathway, changed to a parallel pathway, and finally took the changing career pathway once more. Her employability struggles consisted of learning Swedish, going through mentorship, 
studying a new educational programme, applying for part-time work, trying to get an internship, and finally changing her career twice. Her story raises questions about age discrimination and what it is like to be seen as overqualified in HR work in Sweden.

\section{Transition pathways and employability struggles}

From the stories of the five NTSs, we identified four transition pathways: linear, parallel, further education, and changing career. By using these pathways, the NTS experienced four types of employability struggles: being overqualified; being an outsider as a student; not being good enough in Swedish; and facing discrimination on the labour market.

Table 2

The summary of non-traditional students' pathways and employability struggles

\begin{tabular}{|l|l|l|}
\hline Name & Transition pathways & Experienced employability struggle \\
\hline Alexandra & Linear pathway & $\begin{array}{l}\text { Not being good enough in Swedish } \\
\text { Being discriminated against in the labour market }\end{array}$ \\
\hline Anastasija & $\begin{array}{l}\text { Linear pathway } \\
\text { Parallel pathway }\end{array}$ & $\begin{array}{l}\text { Not being good enough in Swedish } \\
\text { Being discriminated against in the labour market } \\
\text { Being overqualified }\end{array}$ \\
\hline Clare & $\begin{array}{l}\text { Linear pathway } \\
\text { Parallel pathway } \\
\text { Changing career pathway }\end{array}$ & $\begin{array}{l}\text { Being overqualified } \\
\text { Being discriminated against in the labour market }\end{array}$ \\
\hline Guadelupe & $\begin{array}{l}\text { Linear pathway } \\
\text { Further education pathway }\end{array}$ & Being an outsider as a student \\
\hline Liisa & $\begin{array}{l}\text { Linear pathway } \\
\text { Parallel pathway } \\
\text { Further education pathway }\end{array}$ & $\begin{array}{l}\text { Being an outsider as a student } \\
\text { Being discriminated against in the labour market }\end{array}$ \\
\hline
\end{tabular}

Initially, the NTSs intended to follow the linear pathway. It was perceived as a straightforward path. In the end, though, only Alexandra took this pathway, as she wanted to concentrate on her studies, be a good student, and improve her Swedish. Anastasija, Clare, and Liisa, however, became convinced that they had to switch to the parallel pathway to enhance their employability.

The parallel pathway, starting to work in parallel alongside full-time study as soon as possible, became part of their strategies during their studies. However, the idea that they needed at least two years of work experience in parallel with a diploma from $\mathrm{HE}$ was something that they recognised too late. From the stories of the four students, Anastasija, Clare, Guadelupe, and 
Liisa, only Anastasija was somehow successful; although she did not get a real HR job, her competences from the programme were seen as important.

From these stories, we saw that NTSs changed their decisions along the way and also chose two other pathways as a consequence of their struggles: the further education pathway and the changing career pathway.

Taking the further education path means continuing to study at a master's degree level to become employable. Liisa and Guadelupe considered studying at the master's level in the hopes of being in a better position to find a job in the future. For Guadelupe, the further education pathway was her only choice, as she thought she was not good enough. For Liisa, it was her third chosen path, after she had tried two others and not been successful.

Some NTSs choose to change career and apply for jobs outside the HR sector. Clare already changed profession once when going into the HR programme, but she decided to apply for jobs outside the HR sector as a consequence of not being able to get either a part-time job during her studies or an internship after, and not even a permanent job in her field.

From the NTSs' stories, we also identified four struggles they cope with in becoming employable, something we define as employability struggles: being overqualified; being outsiders as students; not being good enough at Swedish; and facing discriminated on the labour market.

Mature students in particular are regarded as being overqualified by employers when it comes to the part-time jobs available in the HR sector, which leads to a struggle in attaining employment. Work experience from these types of HR jobs seems to be relevant to becoming employable in the HR sector; however, Clare, Alexandra, and Anastasija had difficulties in getting the experience. For Clare, her former career was seen as a disadvantage, and at the same time her lack of HR experience was a disadvantage for getting a job requiring more qualification. She was therefore caught in a double-bind situation, where she had to take a changing career pathway again to be able to become employed.

Another struggle is the study situation in which mature students with non-Swedish origins do not fit into the study group and therefore face the risk of failing both in their studies and in applying for a job. From the narratives, it seems like mature students and younger students in the HR programme, form different study groups during their studies; Alexandra, Anastasija and Clare seemed to belong to the mature group, while Liisa and Guadelupe were outsiders in both groups. The latter two students had difficulties succeeding in exams, and as they had to work to support themselves, they had difficulty in engaging with other students and were exposed to prejudice from their peer students. They seem to be too vulnerable to try to compete on the labour market and choose a further education pathway as a means of gaining more formal competences to increase their employability. 
The NTSs' narratives revealed that being part of the student group seems to be important as a social network for becoming employable, as peer students may be gatekeepers in the recruitment process. Being an outsider, therefore, becomes a disadvantage on the labour market as well.

The NTSs in this study expressed their struggles with not being good enough in Swedish. This was seen as problematic during their studies and even worse for their ability to become employed in the Swedish labour market; although some students are competent and very good in the language, they have anxiety about not being good enough, and perceive problems with not being a perfect match on the labour market.

Finally, the students struggled with expectations, as they can face discrimination on the labour market because of their age and ethnicity. This is something they become aware of during their education and they internalise these anxieties. Alexandra and Anastasija were very worried during their transition but ended up in employment where their ethnic backgrounds were seen as an advantage rather than disadvantage. Clare also, retrospectively, referred to facing discrimination because of her age.

\section{Discussion}

The aim of this article is to explore NTSs' transition from HE to working life from their own life perspective. It adopts a biographical learning perspective (Alheit \& Dausien, 2000; Bron \& Thunborg, 2017; Merrill \& West, 2009). From our analyses of the transitions, we elaborated on the concept of transition pathways as specific periods of movements and changes between HE and working life, and identified the linear, parallel, further education, and changing career pathways. We claim, in accordance with the definition of transition (see Hörschelmann, 2011; Hudson, 1999; Merriam, 2005; Niesel \& Griebel, 2005), that it is not a linear development from one phase to another, but an integral process of biographical learning, in which social background, ethnic background, and previous experiences are of importance. The NTSs had been through different periods of life transition and these experiences seem to form their transition pathways. On the other hand, their transition pathways also seem to be influenced by the collective notions of employability and of having the appropriate competencies required by the labour market (Fejes, 2010; Fotiadou, 2020).

Being a NTS means, from the student's experiences, to struggle with background and previous experiences as well as with employability notions, i.e. employability struggles. Employability struggles can emerge from student biographies, i.e. background and previous experiences of being non-Swedish and lacking language skills that affect their view of their own ability to become 
employable. Other employability struggles emerge from their knowledge about discrimination in the labour market generally or from not being recognised as competent enough or being seen as too skilled in the recruitment process (Osman \& Thunborg, 2019). Still other struggles emerge from experiences of being outsiders as students.

This article supports the idea that Swedish students generally start to struggle earlier with becoming employable (cf. Brooks, 2019; Pitman, 2020) than they did a decade ago (cf. Axelsson, 2008; Edström, 2009; Löfgren Martinsson, 2008; Nilsson, 2016) and that some students even start to struggle with how to become employable when they are choosing their education. Using our categorisation of the literature of transition from HE to working life, there are two ideal types of pathways: the linear and the parallel. Brooks' (2019) studies suggests that students who take a parallel transition pathway, have an active career plan, and actively engage with the labour market have better opportunities to successfully gain employment. According to this article, the parallel pathway also seems to be more successful than the linear pathway from the students' perspective. From our study, an active career plan is, however, no guarantee for successfully gaining employment, and the linear pathway could also be quite successful. We also stress that NTSs change their career plans to navigate between various pathways during their transition to secure employment. The article shows how the policy of employability is socialised by students and leads them to changing their pathways to the parallel pathway to be successful. This pathway, however, seems to be easier to follow if you are 'a young Swedish woman, without too much study and work experience, without a family to support and without difficulties with studies or language' (cf. Thunborg \& Bron, 2017).

The shift towards employability seems to create specific struggles for NTSs who could be seen as overqualified for the jobs available in the HR sector or struggling with not being good enough in Swedish. Being afraid of discrimination also leads to a constant attempt to find different ways to get a job or sometimes to changing careers. Finally, being seen as an outsider as a student creates life struggles that lead to low self-esteem and a further education pathway, a pathway not chosen from interest, but due to struggles with not daring to apply for a job. This might create a situation in which students choose to concentrate on their studies to be able to get a diploma and thereby follow a linear pathway or take the further education pathway that, in turn, can be a disadvantage on the labour market.

The notion of employability, which claims that individuals are responsible for gaining the right competencies, seems to have created a need to take the parallel path in order to secure chances of employment. Clarke (2008) suggests that the discourse of employability pays little attention to 'demographic variables such as age, gender, material status, ethnicity and family responsibi- 
lities or physical characteristics' (Clarke, 2008, p. 267). The successful path to employment that everyone in our study struggles with is mainly built on the collective notion that graduates are young, Swedish, without children or disabilities, and competing only with their employability within an equal labour market. The results support the argument by Moureau and Leathwood (2006) that the discourse of employability has negative consequences for non-traditional graduates in the UK. More research in Sweden is needed to understand how this affects both $\mathrm{HE}$ and the labour market policies and practices.

\section{References}

Alheit, P., \& Dausien, B. (2000). 'Biographicity' as a basic resource of lifelong learning. In P. Alheit, J. Beck, E. Kammler, H. Salling Olesen, \& R. Taylor (Eds.), Lifelong learning inside and outside schools, Vol. 2 (pp. 400-422). Roskilde University.

Axelsson, R-M. (2008). Formbara människor. Högre utbildning och arbete som utsnitt ur läkares och civilingenjörers levnadsbanor. [Flexible people: Higher education and work through physicians' and engineers' life-trajectories] (Linköping Studies in Behavioural Science No. 132). Linköpings universitet. http://www.diva-portal.se/smash/get/diva2:18231/COVER01.pdf

Baert, S., Cockx, B., Gheyle, N., \& Vandamme, C. (2015). Is there less discrimination in occupations where recruitment is difficult? ILR Review, 68(3), 467-500. https://doi. org $/ 10.1177 / 0019793915570873$

Ball, S. J., Reay, D., \& David, M. (2002). 'Ethnic choosing': Minority ethnic students, social class and higher education choice. Race Ethnicity and Education, 5(4), 333-357. https://doi. org $/ 10.1080 / 1361332022000030879$

Blommaert, L., Coenders, M., \& van Tuberger, F. (2014). Discrimination of Arabic-named applicants in the Netherlands: An internet-based field experience examining different phases in online recruitment procedures. Social Forces, 92(3), 957-982. https://doi. org/10.1093/sf/sot124

Brooks, R. (2019). A critical exploration of the influences of class, gender and ethnicity on student engagement with graduate employment opportunities (Doctoral thesis, University of Huddersfield, Huddersfield, UK). Retrieved from http://eprints.hud.ac.uk/id/eprint/35130/

Bron, A., \& Thunborg, C. (2015). Biographical interviewing: The case of non-traditional students in higher education. In SAGE Research Methods Cases Part 1 (p.23). Sage. https:// dx.doi.org/10.4135/978144627305014549309

Bron, A., \& Thunborg, C. (2017). Theorising biographical work form non-traditional students' stories in higher education. International Journal of Contemporary Sociology, 54(2), 111-127.

Bursell, M. (2007). What's in a name? A field experiment test for the existence of ethnic discrimination in the hiring process. (The Stockholm University Linnaeus Center for Integration Studies (SULCIS) Working Paper No. 2007:7). https://www.diva-portal.org/smash/get/ diva2:821429/FULLTEXT01.pdf

Bye, H. H., Horverak, J. G., Sandal, G. M., Sam, D. L., \& van de Vijver, F. J. (2014). Cultural fit and ethnic background in the job interview. International Journal of Cross Cultural Management, 14(1), 7-26. https://doi.org/10.1177/1470595813491237 
Clarke, M. (2008). Understanding and managing employability in changing career contexts. Journal of European Industrial Training, 32(4), 258-284. https://doi.org/10.1108/03090590810871379

Edström, E. (2009, April 22). Wanting to become something: About forming identities in bigher education [Paper presentation]. Third Nordic conference on adult learning: Communication, collaboration and creativity, University of Southern Denmark, Odense, Denmark.

Egerton, M. (2000). Monitoring contemporary student flows and characteristics: Secondary analyses using the Labour Force Survey and the general Household Survey. Journal of Royal Statistical Society, 163(1), 63-80. https://doi.org/10.1111/1467-985X.00157

Fejes, A. (2010). Discourses on employability: Constituting the responsible citizen. Studies in Continuing Education, 32(2), 89-102. https://doi.org/10.1080/0158037X.2010.488353

Fotiadou, M. (2020). Denaturalising the discourse of competition in the graduate job market and the notion of employability: A corpus-based study of UK university websites. Critical Discourse Studies, 17(3), 260-291. https://doi.org/10.1080/17405904.2018.1546606

Fransson, G. (2006). Att se varandra $i$ handling. En jämförande studie av kommunikativa arenor och yrkesblivande för nyblivna fänrikar och lärare [To see each other in action: A comparative study of communicative conditions and the process of becoming for commissioned officers and school teachers] (Doctoral thesis, Lärarhögskolan i Stockholm, Stockholm, SE). https:// www.diva-portal.org/smash/get/diva2:199394/FULLTEXT01.pdf

Hörschelmann, K. (2011). Theorising life transitions: Geographical perspectives. Area, 43(4), 378-383. https://doi.org/10.1111/j.1475-4762.2011.01056.x

Hudson, F. M. (1999). The adult years: Mastering the art of self-renewal. Jossey-Bass.

Johansson, K., af Segerstad, H. H., Hult, H., Dahlgren, M. A., \& Dahlgren, L. O. (2008a). The two faces of political science studies - junior and senior students' thoughts about their education and their future profession. Higher Education, 55(6), 623-636. https://doi. org/10.1007/s10734-007-9079-z

Johansson, K., Kopciewicz, L., \& Dahlgren, L. O. (2008b). Learning for an unknown context: A comparative case study on some Swedish and Polish Political Science student' experiences of the transition from university to working life. Compare, 38(2), 219-231. https://doi. org $/ 10.1080 / 03057920701582764$

Lindberg, O. (2012). 'Let me through, I'm a Doctor!' Professional socialization in the transition from education to work (Doctoral thesis, Umeå universitet, Umeå, SE). http://www.diva-portal. org/smash/get/diva2:512147/FULLTEXT01.pdf

Löfgren Martinsson, M. (2008). Högre utbildning och arbete med personal- och arbetslivsfrågor om professionalisering och utveckling av anställningsbarbet [Human Resource education and work - in terms of professionalization and employability development] (Doctoral thesis, Lunds universitet, Lund, SE). https://lup.lub.lu.se/search/ws/files/5591639/1038653.pdf

Merriam, S. B. (2005). How adult life transitions foster learning and development. New Directions for Adult and Continuing Education, 2005(108), 3-13. https://doi.org/10.1002/ace.193

Merrill, B., \& West, L. (2009). Using biographical method in social research. SAGE.

Moureau, M.-P., \& Leathwood, C. (2006). Graduates' employment and the discourse of employability: A critical analysis. Journal of Education and Work, 19(4), 305-324. https://doi. org/10.1080/13639080600867083

Niesel, R., \& Griebel, W. (2005). Transition competence and resiliency in educational institutions. International Journal of Transitions in Childhood, 1(8), 4-11. 
Nilsson, S. (2007). From bigher education to professional practice. A comparative study of physicians' and engineers' learning and competence use (Linköping Studies in Behavioural Science No. 120). Linköpings universitet. http://liu.diva-portal.org/smash/get/diva2:16805/COVER01.pdf

Nilsson, S. (2016). Employability, employment and the establishment of higher education graduates in the labour market. In M. Tomlinson \& L. Holmes (Eds.), Graduate employability in context: Theory, Research and Debate (1st ed., pp. 65-85). Palgrave Macmillan.

Nilsson, S., \& Nyström, S. (2013). Adult learning, education, and the labour market in the employability regime. European Journal for Research on the Education and Learning of Adults, 4(2), 171-187. https://doi.org/10.3384/rela.2000-7426.rela9007

Nyström, S. (2009). Becoming a professional: A longitudinal study of graduates' professional trajectories from HE to working life (Linköping Studies in Behavioural Science No. 140). Linköpings universitet. http://liu.diva-portal.org/smash/get/diva2:174874/FULLTEXT02.pdf

Ohlsson, U. (2009). Vägen in i ett yrke: En studie av lärande och kunskapsutveckling hos nyutbildade sjuksköterskor [Career Paths - A Study of Newly Qualified Nurses' Learning and Knowledge Development ]. Örebro University.

Osman, A., \& Thunborg, C. (2019). The challenge of recruiting underrepresented groups - Exploring organizational recruitment practices in Sweden. Nordic Journal of Working Life Studies, 9(1), 3-18. https://doi.org/10.18291/njwls.v9i1.113085

Pitman, T., Roberts, L., Bennett, D., \& Richardson, S. (2019). An Australian study of graduate outcomes for disadvantaged students. Journal of Further and Higher Education, 43(1), 45-57. https://doi.org/10.1080/0309877X.2017.1349895

Sargeant, M. (2001). Lifelong learning and age discrimination in employment. Education and the Law, 13(2), 141-154. https://doi.org/10.1080/09539960120068336

Thunborg, C., \& Bron, A. (2017, March 23). Managing expectations - Balancing between being a good student, becoming employable or becoming the right "HR employee" [Paper presentation]. International Interdisciplinary Conference on HRM, University of Gothenburg, Sweden. https://employ.dsw.edu.pl/wp-content/uploads/2015/05/Managing-expectationsBalancing-between-being-a-good-student-becoming-employable-or-becoming-the-_rightHR-employee_.pdf

Thunborg, C., \& Bron, A. (2018). Policies for equality and employability. Consequences for non-traditional students. In B. Merrill, A. Galimberti, A. Nizinska, \& J. GonzálezMonteagudo (Eds.), Continuity and discontinuity in learning careers: Potentials for a learning space in a changing world (pp. 125-131). Brill, Sense.

Thunborg, C., \& Bron, A. (2019). Being in constant transition or recurrent formation. Nontraditional graduates' life transitions before, during and after higher education in Sweden. Studies in the Education of Adults, 51(1), 36-54. https://doi.org/10.1080/02660830.2018.152 3102

Tomlinson, M. (2017). Forms of graduate capital and their relationship to graduate employability. Education + Training, 59(4), 228-352. https://doi.org/10.1108/ET-05-2016-0090

Williams, S., Dodd, L. J., Steele, C., \& Randall, R. (2016). A systematic review of current understandings of employability. Journal of Education and Work, 29(8), 877-901. https://doi. org/10.1080/13639080.2015.1102210

Woodfield, R. (2011). Age and first destination employment from UK universities: Are mature students disadvantaged? Studies in Higher Education, 36(4), 409-425. https://doi. org/10.1080/03075071003642431 


\section{Corresponding authors}

Agnieszka Bron

Department of Education, Stockholm University, Sweden

E-mail: agniesz@edu.su.se

Camilla Thunborg

Department of Education, Stockholm University, Sweden

E-mail: camilla.thunborg@edu.su.se 